\title{
Antimicrobial activity of Uncaria tomentosa against oral human pathogens
}

\author{
Atividade antimicrobiana da Uncaria tomentosa \\ sobre patógenos da cavidade bucal humana
}

Renzo Alberto Ccahuana-Vasquez ${ }^{(a)}$ Silvana Soléo Ferreira dos Santos ${ }^{(b)}$ Cristiane Yumi Koga-Ito(c)

Antonio Olavo Cardoso Jorge ${ }^{(b)}$

(a) Graduate Student, Department of Physiology Sciences, School of Dentistry of Piracicaba, State University of Campinas.

(b) PhDs, Department of Microbiology, University of Taubaté.

(c) $\mathrm{PhD}$, Department of Bioscience and Oral Diagnosis, School of Dentistry of São José dos Campos, São Paulo State University.

\section{Corresponding author:}

Silvana Soléo Ferreira dos Santos Departamento de Odontologia da Universidade de Taubaté

Rua dos Operários, 9, Taubaté - SP - Brazil CEP: 12100-000

E-mail:silvana.soleo@uol.com.br
Abstract: Uncaria tomentosa is considered a medicinal plant used over centuries by the peruvian population as an alternative treatment for several diseases. Many microorganisms usually inhabit the human oral cavity and under certain conditions can become etiologic agents of diseases. The aim of the present study was to evaluate the antimicrobial activity of different concentrations of Uncaria tomentosa on different strains of microorganisms isolated from the human oral cavity. Micropulverized Uncaria tomentosa was tested in vitro to determine the minimum inhibitory concentration (MIC) on selected microbial strains. The tested strains were oral clinical isolates of Streptococcus mutans, Staphylococcus spp., Candida albicans, Enterobacteriaceae and Pseudomonas aeruginosa. The tested concentrations of Uncaria tomentosa ranged from $0.25-5 \%$ in MüellerHinton agar. Three percent Uncaria tomentosa inhibited $8 \%$ of Enterobacteriaceae isolates, $52 \%$ of $S$. mutans and $96 \%$ of Staphylococcus spp. The tested concentrations did not present inhibitory effect on P. aeruginosa and C. albicans. It could be concluded that micropulverized Uncaria tomentosa presented antimicrobial activity on Enterobacteriaceae, S. mutans and Staphylococcus spp. isolates.

Descriptors: Cat's claw; Contact inhibition; Bacteria; Candida albicans.

Resumo: Uncaria tomentosa é uma planta medicinal usada por vários séculos pela população peruana como alternativa de tratamento para diversas doenças. Muitos microrganismos que usualmente não habitam a cavidade bucal humana podem se tornar agentes etiológicos de doenças sob certas condições. O objetivo deste estudo foi avaliar a atividade antimicrobiana de diferentes concentrações de Uncaria tomentosa sobre diferentes cepas de microrganismos isolados de cavidades bucais humanas. Uncaria tomentosa micropulverizada foi testada in vitro para determinar a concentração inibitória mínima (CIM) em isolados microbianos selecionados. Cepas de Streptococcus mutans, Staphylococcus spp., Candida albicans, Enterobacteriaceae e Pseudomonas aeruginosa avaliadas foram isoladas de cavidades bucais humanas. Foram preparadas as concentrações de Uncaria tomentosa entre 0.25 e $5 \%$ em ágar Müeller-Hinton. Uncaria tomentosa a 3\% inibiu $8 \%$ de Enterobacteriaceae, $52 \%$ de $S$. mutans e $96 \%$ de Staphylococcus spp. As concentrações testadas não apresentaram efeito inibitório sobre P. aeruginosa e C. albicans. Concluiu-se que Uncaria tomentosa micropulverizada apresenta atividade antimicrobiana sobre cepas de Enterobacteriaceae, S. mutans e Staphylococcus spp.

Descritores: Unha-de-gato; Inibição de contato; Bactérias; Candida albicans. 


\section{Introduction}

Dental caries is defined as an imbalance in the processes of demineralization and remineralization of the hard tissues of the tooth. Loss of mineral from the hard tissues occurs due to a higher grade of demineralization. Dental caries is a multifactorial pathology which involves a susceptible host, a cariogenic microbiota and a cariogenic diet. These factors must occur simultaneously during a certain period of time for the occurrence of dental caries. ${ }^{16}$ Streptococcus mutans is considered the main etiological agent of caries of smooth surfaces in humans and in animal models. Previous studies showed that mutans streptococci are involved in the initial stages of dental demineralization. ${ }^{3,16}$

Other species of microorganisms that are present in the oral cavity such as Candida albicans and Staphylococcus aureus may also cause pathologies, particularly under specific conditions. Microorganisms of the Enterobacteriaceae family and of the genus Pseudomonas have been extensively studied due to their pathogenic potential. Also, these bacteria are correlated to severe periodontal diseases..$^{22,23}$

Treatment of caries and periodontitis has been performed by clinical procedures. The limitations of the mechanical control of dental biofilm originated several studies on the activity of chemical agents. These products can act interfering in the bacterial adhesion to the dental surface, reducing bacterial proliferation or removing the pre-existing biofilm. ${ }^{16}$

Nowadays, an increase in the number of investigations on new and natural substances in order to evaluate their activity and possible application to control the dental biofilm is observed. ${ }^{27}$

Uncaria tomentosa is a medicinal plant used over the centuries by the indigenous civilization of the peruvian rainforest, as an alternative treatment for different diseases. Studies performed in the last decades proved its antiinflamatory, ${ }^{5,8,17,25}$ antineoplastic, ${ }^{19,20}$ anticonceptive, ${ }^{12}$ immunostimulant ${ }^{18}$ and antioxidant ${ }^{4,11,13}$ properties.

Fitotherapy is a viable alternative for all health professionals in the prevention and treatment of several pathologies. The use of medicinal plants has low cost and has been used for several generations. ${ }^{2}$ Scientific studies on the chemical and pharmacological properties of medicinal plants allow scientists to indicate their proper use. Low toxicity, when correctly employed, is considered one of the main advantages of the treatment with medicinal plants. ${ }^{8,14,26}$ Thus, the aim of the present study was to analyze the effects of Uncaria tomentosa on isolates from the human oral cavity.

\section{Material and Methods}

Micropulverized Uncaria tomentosa (Willd.) DC. originated from Peru was commercially obtained and used in this study $(100 \%$ purity, Farma \& Fórmula, Taubaté, SP, Brazil, batch 009).

One hundred and six strains from the human oral cavity, isolated and phenotypically identified in previous studies ${ }^{6,7,15}$, were included in the experiments. These isolates were maintained in the Collection of Cultures of the University of Taubaté - CCUT (Table 1).

Streptococcus mutans strains were previously inoculated on plates of Mitis Salivarius agar (Difco, Detroit, Michigan, USA); Staphylococcus spp., on Baird-Parker agar (Difco, Detroit, Michigan, USA), Candida albicans, on Sabouraud dextrose agar

Table 1 - Isolates included in the study for the determination of the minimum inhibitory concentration (MIC) of Uncaria tomentosa.

\begin{tabular}{l|l|c}
\hline \multicolumn{1}{c|}{ Genus } & \multicolumn{1}{c}{ Species } & Number of strains \\
\hline Streptococcus & S. mutans & 25 \\
\hline Staphylococcus & S. aureus & 22 \\
& S. intermedius & 3 \\
\hline Candida & C. albicans & 25 \\
\hline Klebsiella & K. pneumoniae & 5 \\
& K. oxytoca & 2 \\
\hline Enterobacter & K. terrigena & 1 \\
\hline Escherichia & E. cloacae & 5 \\
\hline Citrobacter & E. sakazakii & 2 \\
& E. asburiae & 1 \\
\hline Serratia & E. amnigenus & 1 \\
\hline Pantoea & C. coli & 2 \\
\hline Pseudomondii & C. amalonaticus & 1 \\
\hline Total & S. liquefaciens & 1 \\
\hline & S. odorifera & 1 \\
\hline & Pantoea spp. & 2 \\
\hline & P. aeruginosa & 6 \\
\hline & & 106 \\
\hline
\end{tabular}


(Difco, Detroit, Michigan, USA) and Enterobacteriaceae/Pseudomonas aeruginosa, on MacConkey agar (Difco, Detroit, Michigan, USA). The plates were incubated at $37^{\circ} \mathrm{C}$ for 24 hours (and $5 \% \mathrm{CO}_{2}$, for Streptococcus mutans). After the period of incubation, standardized suspensions were obtained in $10 \mathrm{ml}$ of sterile saline solution $(0.85 \% \mathrm{NaCl})$ and adjusted to a turbidity of McFarland No. 1 barium sulfate standard.

Minimum inhibitory concentration (MIC) of Uncaria tomentosa was obtained according to the method of dilution in Müeller-Hinton agar (Difco, Detroit, Michigan, USA). A series of plates containing Müeller-Hinton agar and Uncaria tomentosa at $0.25 \%, 0.5 \%, 1 \%, 2 \%, 3 \%, 4 \%$ and $5 \%$ were prepared. Plates of Müeller-Hinton agar without micropulverized Uncaria tomentosa were included as positive control; $2 \mu \mathrm{g} / \mathrm{mL}$ ciprofloxacin and $1 \mu \mathrm{g} /$ $\mathrm{mL}$ amphotericin $\mathrm{B}$ were used as negative control for bacterial and fungal strains, respectively.

The suspensions of the different microbial strains were inoculated with the aid of a Steers replicator and were incubated at $37^{\circ} \mathrm{C}$ for 24 hours (and $5 \%$ $\mathrm{CO}_{2}$ for $S$. mutans). Readings were performed considering the presence or absence of growth according to Oplustil ${ }^{9}$ (2000). The MIC of micropulverized Uncaria tomentosa that was able to inhibit the growth of the isolates was recorded. All the experiments were performed in duplicate.

\section{Results}

The results obtained on the inhibitory activity of the different concentrations of Uncaria tomentosa against the tested strains can be observed in Table 2 .
Minimal inhibitory concentration (MIC) of Uncaria tomentosa was $3 \%(\mathrm{n}=13)$ for $52 \%$ of the tested S. mutans isolates. Five percent Uncaria tomento$s a$ was the MIC for $60 \%$ of the isolates $(\mathrm{n}=15)$.

Twenty-two strains of $S$. aureus and 3 strains of $S$. intermedius were evaluated (Table 1). Growth of all strains was observed at the concentrations of $0.25 \%, 0.5 \%$ and $1 \%$ Uncaria tomentosa. Two percent Uncaria tomentosa was the MIC for $88 \%$ ( $\mathrm{n}=22$ ) of the Staphylococcus isolates, including 3 strains of S. intermedius. Twenty-four (96\%) of the Staphylococcus isolates were inhibited by 3\% Uncaria tomentosa. S. aureus CCUT 101025 was resistant to all the tested concentrations.

Among the Enterobacteriaceae isolates only one Klebsiella pneumoniae (ATCC 18883) and Citrobacter freundii (CCUT 22001) were inhibited by $2 \%$ and $3 \%$ Uncaria tomentosa, respectively.

The concentrations of Uncaria tomentosa tested in the present study did not inhibit the growth of the C. albicans and P. aeruginosa isolates included in this study.

\section{Discussion}

Antimicrobial properties of several plants have been investigated as alternatives with low toxicity for the prevention and treatment of infectious diseases. Uncaria tomentosa presents components like oxindole alkaloids, triterpens, vegetal steroids, phenolic compound, glicosids, tanin and flavonoids. These compounds may be related to its microbial activity. ${ }^{1,8,10}$

In the present study, the MIC value of 3\% Uncaria tomentosa was registered for $52 \%$ of the S. mutans

Table 2 - Susceptibility of the tested microorganisms to Uncaria tomentosa.

\begin{tabular}{l|c|c|c|c|c|c|c|c|c}
\hline \multirow{2}{*}{ Microorganisms } & \multirow{2}{*}{$\begin{array}{c}\text { Number of tested } \\
\text { isolates }\end{array}$} & \multirow{2}{*}{$\begin{array}{c}\text { Number of } \\
\text { inhibited isolates }\end{array}$} & \multicolumn{5}{c}{ Number of strains with MIC (\%) } \\
\cline { 5 - 10 } & & $0.25 \%$ & $0.5 \%$ & $1 \%$ & $2 \%$ & $3 \%$ & $4 \%$ & $5 \%$ \\
\hline Streptococcus mutans & 25 & 15 & 0 & 0 & 0 & 0 & 13 & 1 & 1 \\
\hline Staphylococcus spp. & 25 & 24 & 0 & 0 & 0 & 22 & 2 & 0 & 0 \\
\hline Candida albicans & 25 & 0 & 0 & 0 & 0 & 0 & 0 & 0 & 0 \\
\hline Enterobacteriaceae & 25 & 2 & 0 & 0 & 0 & 1 & 1 & 0 & 0 \\
\hline Pseudomonas aeruginosa & 6 & 0 & 0 & 0 & 0 & 0 & 0 & 0 & 0 \\
\hline
\end{tabular}

MIC - minimum inhibitory concentration. 
strains. Concentrations of $4 \%$ and $5 \%$ of Uncaria tomentosa inhibited $56 \%$ and $60 \%$ of these microorganisms, respectively. The literature does not register previous studies on the use of this plant against $S$. mutans and other oral microorganisms. Differences in the susceptibility of the isolates to Uncaria tomentosa may be probably related to possible genotypic variations that might be further investigated.

The concentrations of 2 to $3 \%$ of Uncaria tomentosa inhibited from 88 to $96 \%$ of the strains of Staphylococcus spp. This was the major inhibition index registered among the tested microorganisms. Out of the 24 Staphylococcus isolates inhibited, twenty-one were $S$. aureus. This microorganism is related to nosocomial infections, and shows resistance to several antimicrobials. ${ }^{5}$ These results suggest that the possibility of the use of Uncaria tomentosa against this microorganism is very promising and should be better studied. Moreover, Valerio, Gonzales $^{24}$ (2005) cited that animal toxicological studies indicated low potential for acute and subacute oral toxicity of Uncaria tomentosa.

No activity of Uncaria tomentosa on C. albicans growth was observed in this study. This result differs from that presented by Silva et al. ${ }^{21}$ (1998). These authors registered $66 \%$ of inhibition of C. albicans isolates. This difference may be related to the concentration and type of Uncaria tomentosa employed in the experiments. In this study we used micropulverized Uncaria tomentosa up to $5 \%(50 \mathrm{mg} /$

\section{References}

1. Aquino R, de Tommasi N, de Simone F, Pizza C. Triterpenes and quinovic acid glycosides from Uncaria tomentosa. Phytochemistry. 1997;45(5):1035-40.

2. Gebara E, Zardetto C, Mayer M. Estudo in vitro da ação antibacteriana de substâncias naturais sobre $S$. mutans e S. sobrinus. Rev Odontol Univ São Paulo. 1996;10(4):251-6.

3. Hamada S, Slade HD. Biology, immunology and cariogenicity of Streptococcus mutans. Microbiol Rev. 1980;44(2):33184.

4. Keplinger K, Laus G, Wurm M, Dierich MP, Teppner H. Uncaria tomentosa (Willd.) DC. - Ethnomedicinal use and new pharmacological, toxicological and botanical results. J Ethnopharmacol. 1999;64(1):23-34.

5. Lahoud V, Ilizarbe S, Ballona P. Estudio radiográfico comparativo del recubrimiento pulpar indirecto con pasta base de ml). Silva et al. ${ }^{21}$ (1998) used a freeze-dried extract at a concentration of $500 \mathrm{mg} / \mathrm{ml}$.

Three percent Uncaria tomentosa was effective to inhibit the growth of $8 \%$ of Enterobacteriaceae $(2 / 25)$ isolates, being one strain of $C$. freundii (CCUT 22001) and one of K. pneumoniae (ATCC 18833). Silva et al. ${ }^{21}$ (1998) evaluated a freeze-dried extract of Uncaria tomentosa on E. coli isolates and observed growth inhibition with disks containing $8.7 \mathrm{mg}$. In this study, 2 strains of E. coli were tested (CCUT 71003 and ATCC 25922) and no inhibition was observed.

No growth inhibition of $P$. aeruginosa was observed even at the concentration of $5 \%$ of Uncaria tomentosa. P. aeruginosa is an important pathogen with high resistance to different compounds and also several antimicrobials. ${ }^{15}$

More detailed studies must be developed on the identification of chemical compounds of Uncaria tomentosa and the correlation with the antimicrobial activity. Data on the antimicrobial activity on pathogens are important for the future application of this plant in medicine and dentistry.

\section{Conclusions}

It could be concluded that micropulverized Uncaria tomentosa presented antimicrobial activity on Enterobacteriaceae, S. mutans and Staphylococcus spp. isolates, however it did not present inhibitory effect on $P$. aeruginosa and C. albicans.
Uncaria tomentosa vs. hidróxido de calcio y cemento óxido de zinc-eugenol. Odontol Sanmarq. 2000;1(6):9-19.

6. Loberto JCS, Martins CAP, Santos SSF, Cortelli JR, Jorge AOC. Staphylococcus spp. in the oral cavity and periodontal pockets of chronic periodontitis patients. Braz J Microbiol. 2004;35(1):64-8.

7. Martins CAP, Santos SSF, Loberto JCS, Koga-Ito CY, Jorge AOC. Presença de Candida spp. em pacientes com periodontite crônica. Cienc Odontol Bras. 2002;5(3):75-83.

8. Obregón Vilches L. Uña de gato. Género Uncaria. Estudios Botánicos, químicos y farmacológicos de Uncaria tomentosa y Uncaria guianensis. Lima: Instituto de Fitoterapia Americano; 1996.

9. Oplustil CP. Testes de avaliação da resistência aos antimicrobianos. In: Oplustil CP, Zoccoli CM, Tobouti NR. Procedimentos 
básicos em microbiologia clínica. São Paulo: Sarvier; 2000. p. 33-61.

10. Otake S, Makimur M, Kuroki T, Nishihara Y, Hirasawa M. Anticaries effects of polyphenolic compounds from japanese green tea. Caries Res. 1991;25(6):438-43.

11. Pilarski R, Zielinski H, Ciesiolka D, Gulewicz K. Antioxidant activity of ethanolic and aqueous extracts of Uncaria tomentosa (Willd.) DC. J Ethnopharmacol. 2006;8:104(12):18-23.

12. Salazar EL, Jayme V. Depletion of specific binding sites for estrogen receptor by Uncaria tomentosa. Proc West Pharmacol Soc. 1998;41:123-4.

13. Sandoval M, Charbonnet RM, Okuhama NN, Roberts J, Krenova Z, Trentacosti AM et al. Cat's claw inhibits TNFalpha production and scavenges free radicals: role in cytoprotection. Free Radic Biol Med. 2000;29(1):71-8.

14. Santa María A, Lopez A, Diaz MM, Alban J, Galan de Mera A, Vicente Orellana JA et al. Evaluation of the toxicity of Uncaria tomentosa by bioassays in vitro. J Ethnopharmacol. 1997;57(3):183-7.

15. Santos SSF, Loberto JCS, Martins CAP, Jorge AOC. Prevalência e sensibilidade in vitro de Enterobacteriaceae e Pseudomonas isoladas da cavidade bucal e bolsa periodontal de pacientes com periodontite crônica. RPG Rev Pós-Grad. 2002;5(2):74-83.

16. Seif T. Cariología: prevención, diagnóstico y tratamiento contemporáneo de la caries dental. Caracas: AMOLSA; 1997.

17. Setty AR, Sigal LH. Herbal medications commonly used in the practice of rheumatology: mechanisms of action, efficacy and side effects. Semin Arthritis Rheum. 2005;34(6):773-84.

18. Sheng Y, Bryngelsson C, Pero R. Enhanced DNA repair, immune function and reduced toxicity of C-MED-100, a novel aqueous extract from Uncaria tomentosa. J Ethnopharmacol. 2000;69(2):115-26.
19. Sheng Y, Pero RW, Amiri A, Bryngelsson C. Induction of apoptosis and inhibition of proliferation in human tumor cells treated with extracts of Uncaria tomentosa. Anticancer Res. 1998;18(5A):3363-8.

20. Sheng Y, Pero W, Wagner H. Treatment of chemotherapyinduced leukopenia in a rat model with aqueous extract from Uncaria tomentosa. Phytomedicine. 2000;7(2):137-43.

21. Silva DH, Alvarado DR, Hidalgo HJ, Cerrutti ST, Garcia RJ, Dávila MW et al. Monografia de Uncaria tomentosa (Willd.) DC. Iquitos, Peru: Instituto Peruano de Seguridad Social/Instituto de Medicina Tradicional; 1998.

22. Slots J, Feik D, Rams TE. Prevalence and antimicrobial susceptibility of Enterobacteriaceae, Pseudomonadaceae and Acinetobacter in human periodontitis. Oral Microbiol Immunol. 1990;5(3):149-54.

23. Slots J, Rams TE. New views on periodontal microbiota in special patient categories. J Clin Peridontol. 1991;18(6):41120.

24. Valerio LG Jr, Gonzales GF. Toxicological aspects of South American herbs cat's claw (Uncaria tomentosa) and Maca (Lepidium meyenii): a critical synopsis. Toxicol Rev. 2005;24(1):11-35.

25. Winkler C, Wirleitner B, Schroecksnadel K. In vitro effects of two extracts and two pure alkaloid preparations of Uncaria tomentosa on peripheral blood mononuclear cells. Planta Med. 2004;70(3):205-10.

26. Wolinsky LE, Mania S, Nachnani S, Ling S. The inhibiting effect of aqueous Azadirachta indica (Neem) extract upon bacterial properties influencing in vitro plaque formation. J Dent Res. 1996;75(2):816-22.

27. Wu-yuan CD, Chen CY, Wu RT. Gallotannins inhibit growth, water soluble glucan synthesis, and aggregation of mutans Streptococci. J Dent Res. 1988;67(1):51-5. 